\title{
Evaluation of Rice Markets Integration in Bangladesh
}

\author{
Mohammad Ismail Hossain* and Wim Verbeke ${ }^{* *}$
}

\begin{abstract}
The liberalization of the agricultural sector in general and the rice subsector in particular has been a major component of Bangladesh's structural adjustment program initiated in 1992. However, the government has continued to intervene in the rice subsector. This paper examines whether the regional/divisional rice markets have become spatially integrated following the liberalization of the rice market. Wholesale weekly coarse rice prices at six divisional levels over the period of January 2004 to November 2006 were used to test the degree of market integration in Bangladesh using co-integration analysis and a vector error correction model (VECM). The Johansen co-integration test indicated that there are at least three co-integrating vectors implying that rice markets in Bangladesh during the study period are moderately linked together and therefore the long-run equilibrium is stable. The short-run market integration as measured by the magnitude of market interdependence and the speed of price transmission between the divisional markets has been weak.
\end{abstract}

Keywords: Market liberalization, integration; vector error correction model, rice, price transmission, Bangladesh.

JEL Classification: D 40, Q 13.

\section{Introduction}

While globalization and liberalization has opened up new avenues of international and regional trade, the gains of liberalization, accrue to the producers-sellers and consumers only if agriculture and food supply chains become efficient, competitive, and innovative not only in production but also in marketing. In the past 20 years, a number of Asian countries including Bangladesh have adopted market-oriented policies resulting in the reduction of government intervention in agricultural markets. The general consensus among economists and

\footnotetext{
* PhD Candidate, Department of Agricultural Economics, Faculty of Agriculture, Aristotle University of Thessaloniki, Greece.

${ }^{* *}$ Professor, Department of Agricultural Economics, Faculty of Bioscience Engineering, Ghent University, Belgium.
} 
policymakers is that market liberalization enhances economic growth whereas intervention policies inhibit it (FAO, 1987; Onafowora and Owoye, 1998). Unless agricultural markets are integrated, producers and consumers will not realize the gains from liberalization, since the correct price signals will not be transmitted through the marketing channels and as a result farmers will not be able to specialize according to long-term competitive advantages. Finally, the potential gains from trade will not be realized in full (Ravallion, 1986). Therefore, in the past years a number of developing countries have adopted market-oriented policies, characterized by a reduction and/or complete elimination of the main market distortions. Within agriculture, particularly the food grains subsector, these have included the removal of restrictions on interregional trade of food grains by traders; elimination of regional and seasonal pricing; and reform or even complete abolition of government parastatal marketing organizations for allowing greater private sector participation. Rice markets in Bangladesh underwent major liberalization during the late 1980s and early 1990s.

Market integration is a central issue in many contemporary debates concerning market liberalization. It is perceived as a precondition for effective market reform in developing countries: "Without spatial integration of markets, price signals will not be transmitted from urban food deficit to rural food surplus areas, prices will be more volatile, agricultural producers will fail to specialize according to long term comparative advantage and gains from trade will not be realized" (Baulch, 1997, p. 477).

An indirect method of analyzing market efficiency is to test for market integration (Hopcraft, 1987). A basic issue preoccupying many researchers is whether market liberalization enhances the integration of spatial markets (Silumbu, 1992; Goletti and Babu, 1994; Goletti et al., 1995; Barrett, 1996; Dercon, 1995, Getnet et al.; 2005). Silumbu (1992) used monthly wholesale prices to test for the spatial and inter-temporal market integration of maize markets in Malawi and found that the integration of urban markets had increased slightly even under partial liberalization. Goletti and Babu (1994) used different measures of integration and monthly retail maize prices for eight regional markets in Malawi. They concluded that the liberalization of the maize market had increased market integration. Goletti et al. (1995) used weekly wholesale prices of rice to test the structural determinants of market integration in the rice market in Bangladesh and concluded that the degree of rice market integration in Bangladesh is moderate. Baulch et al. (1998) studied the spatial integration 
and pricing efficiency of the private sector grain trade in Bangladesh and provided econometric evidence suggesting that wholesale markets for rice are in fact well integrated, except for periods of major shortages in domestic production (such as those just after the 1997/98 and 1998/99 Aman harvests). Finally, Getnet et al. (2005) studied the spatial equilibrium of grain markets (white teff) in Ethiopia by using the co-integration technique and provided evidence of domestic market integration.

For spatially dispersed regional food markets, as exist in many Asian countries, the nature and extent of market integration in the context of food market liberalization is of vital importance, since many of the regional food markets are characterized by periodic food shortages which have the potential to generate transient food insecurity and sometimes even chronic food security problems. Merely knowing that markets are integrated is not enough. It is necessary to know the extent of spatial market integration within the context of market integration. This paper uses cointegration analysis to formally test whether rice markets in Bangladesh have become integrated.

\section{Methodology}

The model of spatial integration predicts that, under competitive conditions, price differences between two regions in the same economic market for a homogeneous commodity will approximately equal the inter-regional transportation costs. Market integration thus involves a test of price efficiency by examining how food markets in different regions respond jointly to supply and demand forces. If price movements in different parts of the country tend to behave similarly, reflecting the cost of transferring the product between two regions, then markets are said to be integrated.

Several studies on market liberalization have tested for food market integration (Gupta and Mueller, 1982; Hytens, 1986; Ravallion, 1986; Silumbu, 1992; Alexander and Wyeth; 1994; Goletti and Babu, 1994; Dercon, 1995; and Goletti et al., 1995; Goletti et al., 1994). Early empirical studies of market integration used static price correlations to test for spatial market integration in agricultural markets (Jones, 1968; 1972; Farruk, 1970; and Lele, 1972). This involves the estimation of bivariate correlation or regression coefficients between the time series of spot prices for an identical good at different market places. In these analyses, a statistically significant coefficient implies that the two markets are integrated. This kind of modeling of spatial market integration has been criticized for masking other 
effects like inflation and seasonality. Price correlation assumes instantaneous price adjustment and cannot capture the dynamic nature of a marketing system (Heytens, 1986; Ravallion, 1986 and Sexton et al., 1991). It is possible that price correlation might suggest be the result of spurious market integration, like common trends, common seasonality, monopoly price fixing, etc. (Harriss, 1979; Delgado, 1986; and Heytens, 1986). Price correlation tests may also overestimate a lack of market integration if a lag in market information produces a lag in the price response between markets (Barrett, 1996). Finally, price correlation tests only a pair of markets at a time and cannot be used to evaluate the marketing system as a whole (Delgado, 1986). In order to overcome the weaknesses of price correlation tests, various alternative methods have been developed (Delgado, 1986; Ravallion, 1986; Engle and Granger, 1987 and Johansen, 1988).

Time series methods have been introduced in the study of market integration to overcome the problems of common trends and nonstationarity of food prices inherent in bivariate price correlation models. Studies employing time series methods also formally modeled issues pertaining to short-run and long-run integration, seasonality, and the degree of market integration (Boyd and Brosern, 1986; Delgado, 1986; and Ravallion, 1986).

The Granger causality method employs an error correction mechanism to determine the extent to which current and past price changes in one market explain price changes in another. The error correction model (ECM) (Engle and Granger, 1987) holds that if the price of a local market and the price of the central market are co-integrated, then the error term from the co-integrating equation should be included, otherwise a first differencing regression between the two prices will be mis-specified and cannot be used to test for market integration (Palaskas and Harriss, 1993; Dercon, 1995). The advantage of the ECM is that not only can short-run and long-run information be conveyed between markets, but the relevant direction of the flow of price information can also be determined. Another advantage of the ECM is that it helps to alleviate the problems of auto-correlation and multicollinearity of most food price series (Baulch, 1997). The shortcoming of Granger cointegration analysis is that it does not allow for the investigation of all possible co-integrating vectors in a multivariate system (Myers, 1994; Fackler, 1996).

Johansen (1988) developed a multivariate method of cointegration analysis which is a more recent development in this field. The 
method uses a maximum likelihood methodology to test the hypothesis of co-integrating relationships among several economic time series. The use of multivariate analysis is the most suitable approach to use if prices are endogenously determined, which is usually the case for food markets, and in which prices are simultaneously determined. The multivariate approach was used by Silvapulle and Jayasuriya (1994) in their study of Philippine rice markets to study the co-integration of markets; they found that rice markets were co-integrated. Chang and Griffith (1998) applied the multivariate approach to Australian monthly beef prices at the farm, wholesale, and retail levels and found all three prices to be co-integrated.

For the present study, there is some validity in the above mentioned criticisms especially as far as non-stationary transfer costs are concerned. Nonetheless, time series analysis can provide useful insights into the issue of market integration if an appropriate testing framework is employed and the results are interpreted correctly. Co-integration tests and ECMs provide an analytical tool that can focus beyond the case of market integration in testing notions such as completeness, speed, and asymmetry of the relationship between prices.

In analyzing spatial integration, data on daily prices or average weekly prices are preferable. Like other developing countries, in Bangladesh, daily prices are available for only a few central markets and only for a short period of time. For the purpose of this study, data pertaining to weekly wholesale rice prices were collected from different marketing intelligence centers (MICs) as assigned by the Department of Agricultural Marketing, Government of the People's Republic of Bangladesh, for the period January 2004 to November 2006. Data on prices pertain to Friday of each week for twelve months. The prices were reported in Tk/quintal. The selected six MICs for this study were Dhaka, Chittagong, Rajshahi, Khulna, Barisal, and Sylhet.

The individual price series are tested for the order of integration to determine whether or not they are stationary. A number of tests for stationarity are available in the literature; these include the Dickey-Fuller (DF) test (Dickey and Fuller, 1979), the Augmented Dickey-Fuller (ADF) test (Dickey and Fuller, 1981) and the Philips-Perron (PP) test (Perron, 1988). Having established that the variables are nonstationary a maximum likelihood approach based on a finite vector autoregression (VAR) model as developed by Johansen (1991) can be specified to determine whether the system of equations are co-integrated. The model is: 


$$
X_{t}=A_{0}+A_{1} X_{t-1}+\ldots+A_{p} X_{t-p}+v_{t} ; \mathrm{t}=1,2, \ldots \mathrm{T},
$$

where $\mathrm{p}=$ lag length; $X_{t}=a(n \times 1)$ vector of endogenous variables; $A^{\prime}$ s are matrices of unknown parameters; and $v_{t}$ is an independently and identically distributed $\mathrm{n}$ dimensional vector with zero mean and variance matrix $\varepsilon_{t}$. The next step is specifying a VAR model in an error correction form. Following Johansen (1988) and Johansen and Juselius (1990), a general system of regression equations is stipulated as:

$$
\Delta X_{t}=\tau_{0}+\tau_{1} \Delta X_{t-1}+\ldots+\tau_{p-1} \Delta X_{t-(p-1)}+\Pi X_{t-p}+v_{t}
$$

or

$$
\Delta X_{t}=\tau_{0}+\sum_{j=1}^{p-1} \tau_{j} \Delta X_{\mathrm{t}-1}+\Pi \mathrm{X}_{\mathrm{t}-\mathrm{p}}+v_{\mathrm{t}}
$$

Where $\tau_{0}=\mathrm{A}_{0}$;

$$
\begin{aligned}
& \tau_{j}=-\left(I-\sum_{j=1}^{p-1} A_{j}\right) ; \mathrm{j}=1,2 \ldots . ., \mathrm{p}-1 \\
& \Pi=-\left(I-\sum_{i=1}^{p} A_{i}\right)
\end{aligned}
$$

and $\Delta X_{t-j}$ is an $(n \times 1)$ vector of $X_{t-j}$ in first differences, and $\Pi$ and $\tau_{j}(j=1,2$, $\ldots . ., k$ ) are $n$ by $n$ matrices of parameters and $V_{t}$ is an $n$-vector of residuals which are assumed to be normally distributed with mean zero and have a contemporaneous covariance matrix $\varepsilon_{t}$. The long-run information in $X_{t}$ is summarized by the long-run impact matrix $\Pi$. $\Pi$ is the rank of the matrix of the VECM that determines the number of independent co-integrating vectors. If the matrix $\Pi$ has a rank, r, greater than 0 , then co-integration exists. If the rank of $\Pi$ is 0 , then the variables are segmented and the model translates into a standard VAR model in differences.

\section{Results and Discussion}

The original data for the six selected divisional markets are shown in Figure 1 while the logarithm of the six divisional market price series and their first difference series are presented in Figures 2 and 3. It can be 
seen from the figures that there are some spatial variations between the divisional markets as well as some seasonal variations.

Figure 1: Nominal wholesale rice prices of six regional divisions in Bangladesh (weekly data from January 7, 2004 to November 29, 2006)

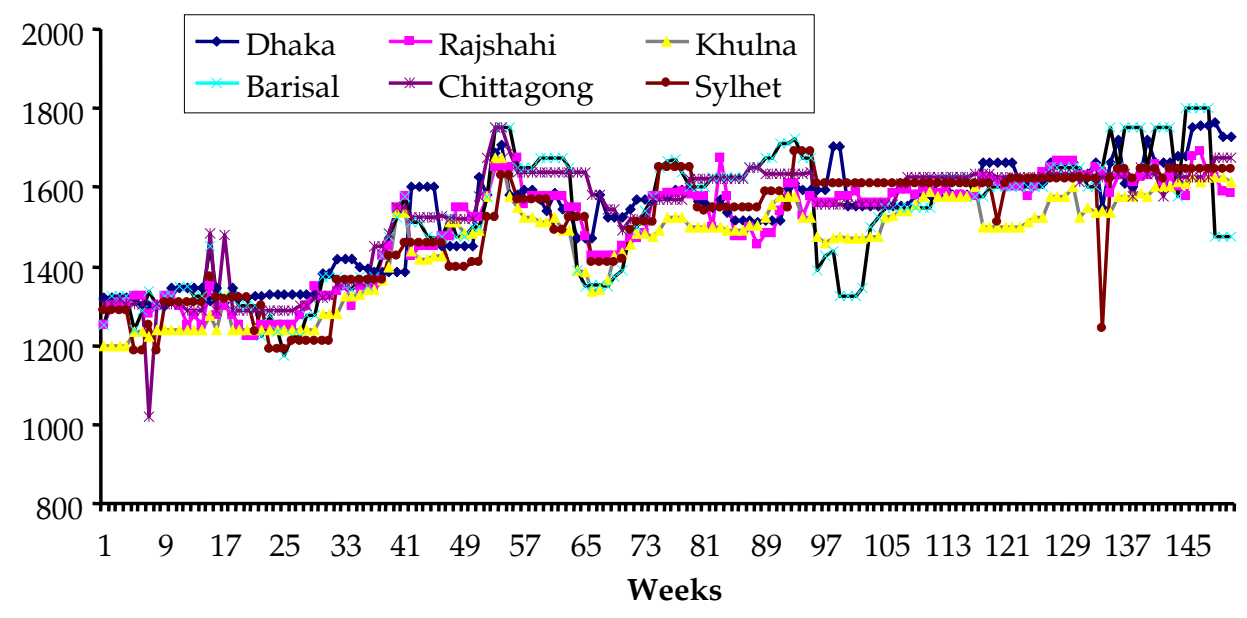


Figure 2: Weekly Log Wholesale Divisional Rice Prices in Levels
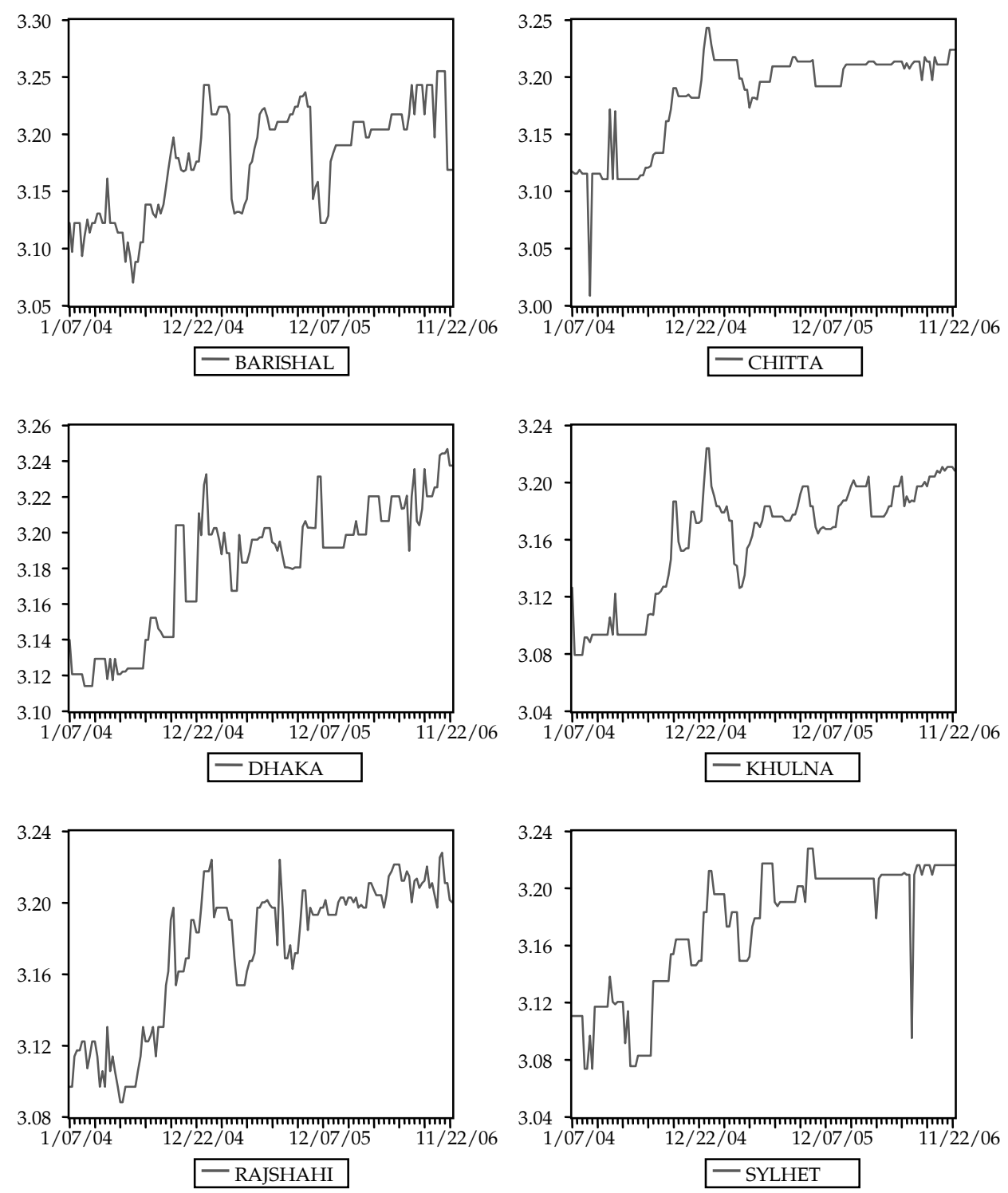
Figure 3: Weekly Log Wholesale Divisional Rice Prices in First Difference
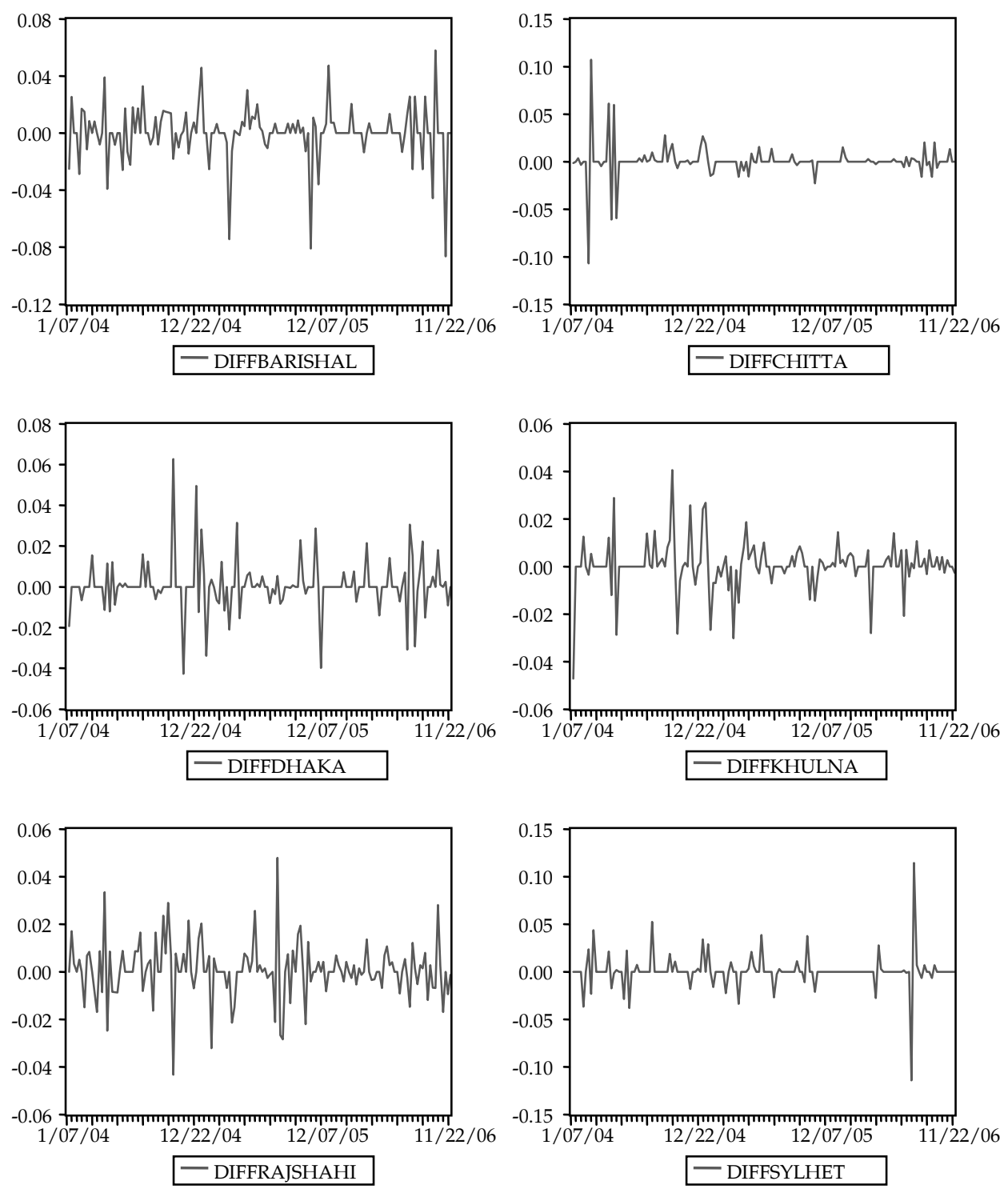

\subsection{Co-Integration Analysis Results}

For the multivariable model, co-integration is tested using Johansen's maximum likelihood procedure using two test statistics, namely the trace and eigenvalue. The maximum lag was 2, based on the Akaike Information Criterion (AIC) and Schwartz Criterion (SC). The test results are presented in Table-1. 
The results of $\lambda_{\text {trace }}$ using the Johansen co-integration test indicate that the rank of $\Pi$ can reach 3 (at 95\% level of significance) which means that there are at least three co-integrating equations in our estimation. If we select $r=4$ then the $\lambda_{\text {trace }}$ value is smaller than the critical value. The results from these trace statistics indicate that there are three co-integrating vectors and three common trends which suggest that rice markets are stationary in three directions and nonstationary in three directions. This indicates that the rice markets in Bangladesh during the study period are moderately linked together and that therefore the long-run equilibrium is stable. This finding is supported by the earlier studies carried out Goletti et al. (1995) and Baulch et al. (1998) who also concluded that the degree of market integration in Bangladesh was moderate.

\subsection{Causality and Integration of Rice Markets}

Before the Granger causality test was carried out, the VECM was tested for the presence of any diagnostic problems to check the adequacy of the model. The model was found to have no major diagnostic problems, i.e., the variables were found to be nonstationary in levels and stationary in differences.

The results for causality tests are inferred from the $\mathrm{F}$ statistic shown in Table-2. The results indicate the strength of causality from regional market $\mathrm{C}$ to regional market $\mathrm{L}$ and vice versa. A Granger causality test to establish the appropriate direction of the flow of price information is implied if the null hypothesis that there is no causality from $C$ to $L$ or $L$ to $C$ is rejected.

Table-1: Results of Co-Integration Analysis

\begin{tabular}{lcrc}
\hline Null hypothesis & $\begin{array}{c}\text { Maximum eigenvalue } \\
\left(\boldsymbol{\lambda}_{\text {max }}\right)\end{array}$ & $\begin{array}{c}\text { Trace statistic } \\
\left(\mathbf{V}_{\text {trace }}\right)\end{array}$ & $\begin{array}{c}\mathbf{9 5 \%} \\
\text { critical value }\end{array}$ \\
\hline $\mathrm{r}=0$ & 0.286 & $131.455^{* * *}$ & 102.14 \\
$\mathrm{r}=1$ & 0.172 & $81.271^{* *}$ & 76.07 \\
$\mathrm{r}=2$ & 0.124 & $53.179^{* *}$ & 53.12 \\
$\mathrm{r}=3$ & 0.116 & 33.514 & 34.91 \\
$\mathrm{r}=4$ & 0.070 & 15.194 & 19.96 \\
$\mathrm{r}=5$ & 0.029 & 4.321 & 9.24 \\
\hline
\end{tabular}

Note: $\left.{ }^{* *}{ }^{* * *}\right)$ denotes rejection of the hypothesis at 5\% (1\%) significance level.

If $\lambda_{\text {trace }}$ value exceeds the critical value, the null hypothesis is rejected.

Source: Weekly rice price series 7, 2004 to November 29, 2006 collected from DAM. 
Table-2: Granger Causality Test Results

\begin{tabular}{lcccccc}
\hline From & \multicolumn{5}{c}{ To market L } \\
\cline { 2 - 7 } market C & Dhaka & Chittagong & Rajshahi & Khulna & Barisal & Sylhet \\
\hline Dhaka & & $4.492^{* *}$ & $5.57^{* * *}$ & 2.05 & 1.53 & $7.69^{* * *}$ \\
Chittagong & $5.94^{* * *}$ & & 1.22 & 1.57 & $2.55^{*}$ & $8.27^{* * *}$ \\
Rajshahi & $10.92^{* * *}$ & $4.89^{* * *}$ & & 0.34 & $3.92^{* *}$ & $9.78^{* * *}$ \\
Khulna & $12.95^{* * *}$ & $9.13^{* * *}$ & $10.01^{* * *}$ & & $6.21^{*}$ & $15.12^{* * *}$ \\
Barisal & $8.57^{* * *}$ & $4.53^{* *}$ & $3.48^{* *}$ & 0.62 & & $7.70^{* * *}$ \\
Sylhet & 1.16 & $2.84^{*}$ & $2.73^{*}$ & 0.87 & 1.49 & \\
\hline
\end{tabular}

Note: The figures indicate the calculated F values associated with the hypothesis that there is no Granger causality from market $C$ to $L$ and vice versa and from appendix Table-3.

* Significance at the $10 \%$ level ** Significance at the 5\% level *** Significance at the $1 \%$ level.

Source: Weekly rice price series from January 7, 2004 to November 29, 2006 collected from DAM.

The results suggest that price changes in Dhaka "Granger-cause" price changes in Rajshahi and Sylhet at a 1\% level of significance and those in Chittagong at 5\%. Price changes in Dhaka are however Grangercaused by those in Chittagong and Rajshahi at 1\%. This indicates a twoway causation of prices between Dhaka and Chittagong and Dhaka and Rajshahi. The results for Rajshahi and Chittagong are as expected since Rajshasi is a major surplus region and Chittagong is a deficit region and also an importing region of rice. No causality was found from Dhaka to Khulna and Barisal, and from Sylhet to Dhaka. This implies that Dhaka to Khulna and Barisal and Sylhet to Dhaka; Dhaka leads the price formation process for only Sylhet. However, there was bi-directional causality between Dhaka and Chittagong, and Dhaka and Rajshahi. Thus, Dhaka cannot be considered a central market.

Chittagong is an urban deficit region and situated in the southern part of Bangladesh. The results reveal bi-directional causality with Dhaka, Barisal and Sylhet; and unidirectional causality from Khulna to Chittagong and from Rajshahi to Chittagong. It is said that Chittagong is not a major central market for the other regional centers. Rajshahi is a major surplus region and has unidirectional Granger causality with Chittagong, insignificant causality with Khulna, and bi-directional causality with Dhaka, Barisal, and Sylhet. Khulna is another surplus region and has significant unidirectional causality with all five regions. The Khulna region is a price leader for all other regions, which is unexpected. 
On the basis of the Granger causality results, we conclude that there is no dominant market whose price changes influence all other markets. The bivariate model reveals that price changes in Bangladesh appear to be organized around more than one market. These results are in line with the nature of markets in developing countries, in that those markets are usually more complex than is portrayed by the Ravallion radial configuration of markets. These results are similar to what Silvapulle and Jayasuriya (1994) found in their analysis of rice markets in the Philippines.

\subsection{Dynamic Analysis of Rice Market Integration}

It is not sufficient to know that markets are integrated. It is also important to know the extent to which markets are integrated. This requires distinguishing between the short- and long-run impacts of price changes emanating from one region to another. The speed of adjustment, the length of time needed for prices to be transmitted from one market to another, can be studied by dynamic adjustments.

A vector autoregression model was first estimated with four lags, the number of lags chosen based on the AIC and SC criteria. Beginning with four lags, the lagged variables were tested for the significance and only the variables that were significant were included in the final VECM. This yielded a VECM with two lags (determined by the smallest values of AIC and SC). The finding of three co-integrating vectors and three common trends means that three prices can be expressed in terms of the other three prices. For example, if we normalize the long-run relationship by the price changes in Rajshahi the result can be interpreted as the longrun price response function for the other three prices. 
The long-run co-integration of price series can be seen by analyzing the normalized co-integrating coefficients $(\beta)$. To estimate cointegrating coefficients $(\beta)$, we used the Johansen co-integration test. If we normalize the long run relationships by the price changes in Rajshahi, Sylhet, and Khulna, respectively, the three normalized co-integrating equations are as follows:

$$
\begin{aligned}
& \text { RAJSHAHI }=1.044 \text { DHAKA }-0.201 \text { CHITTAGONG + 0.256 BARISAL }-0.322 \\
& (-5.218)^{* * *} \\
& (-1.756)^{*} \\
& \text { SYLHET }=0.991 \text { DHAKA }+0.323 \text { CHITTAGONG }-0.170 \text { BARISAL }-0.468 \\
& (-3.346)^{* * *} \quad(-0.968) \\
& (-3.660)^{* * *} \quad(-3.495)^{* * *} \quad(-0.338)
\end{aligned}
$$

Note: All figures in parentheses indicates t values.

*** Significant at $1 \%$ and *Significant at $10 \%$.

Equation (1) indicates that a $1 \%$ increase in prices in Dhaka results in a $1.04 \%$ increase in prices in Rajshahi whereas a $1 \%$ increase in prices in Chittagong decreases prices in Rajshahi by $0.2 \%$. This implies that, as Chittagong is a rice-importing region and Rajshahi a rice-producing region, the gains of price increases do not transfer from Chittagong to Rajshahi. The gains are captured by marketing agencies, not by farmers. Due to the longer distance between Chittagong and Rajshahi, price signals were not transmitted accurately and correctly. Prices in Rajshahi increase by $0.26 \%$ if prices in Barisal increase by $1 \%$. Equation (2) and (3) contain a similar interpretation.

The short-run dynamics among these variables can be evaluated by examining the significance and signs of the estimated lagged coefficients which are presented in Table-3. The short-run results from the VECM revealed that all the estimated short run coefficients except for four are statistically insignificant at the 5\% level. The coefficients' values range between 0.004 and 0.40 . This suggests that the transmission of price changes from one market to another during the same week is weak. The speed of adjustment is given by the size of the adjustment coefficient. In co-integration equation 1, price changes in Rajshahi and Barisal during the studied period were transmitted to other markets at a rate of $22 \%$ and $24 \%$, respectively, within a week. On the other hand, adjustment toward the long run is especially slower in the case of price changes in Sylhet $(0.6 \%)$, Khulna (5\%), Dhaka (21\%), and Chittagong (13\%). In the case of 
equation 2, only Sylhet (36\%) showed faster transmission and in equation 3 , Chittagong (43\%) showed faster adjustment.

\section{Conclusions and Implications}

Using weekly market price data for the period 2004-2006 from six regional markets in Bangladesh, this study has investigated the nature and extent of market integration after rice market liberalization. The overall results of the market integration analysis in Bangladesh indicate that, although the six regional markets in Bangladesh are co-integratedmeaning that they have a stable long run relationship-these markets are only weakly integrated in the short run. The results from trace statistics show that there are three co-integrating vectors and three common trends, which suggest that rice markets are stationary in three directions and nonstationary in three directions. Granger-causality results indicated that there was unidirectional causality originating from Dhaka to Khulna and Barisal, and from Sylhet to Dhaka, while Dhaka leads the price formation process only for Sylhet. There was also bi-directional causality between Dhaka and Chittagong, and Dhaka and Rajshahi. The short-run results indicate that these rice markets are not well integrated while long-run integration is evident, suggesting that the markets do eventually move together in the long term. The spread of adjustment appears to be the inverse of distance and directly related with ease of transport. The policy implications of these results is that structural rigidity resulting from poor infrastructure and insufficient transportation networks hampers the easy flow of information between markets and therefore the integration of markets in the short run. Thus, in order for rice surplus regional markets to be better integrated with deficit regions, the government should invest in better transportation and infrastructure facilities.

Table-3: Long-Run and Short-Run Integration Estimates from the Vector Error Correction Estimates Model

\begin{tabular}{lcccccc}
\hline & D(RAJSHAH & D(SYLHE & D(KHULN & D(DHAK & D(CHITT & D(BARISA \\
& I) & T) & A) & A) & A) & L) \\
\hline CointEq1 & -0.221 & 0.005 & -0.045 & 0.214 & -0.133 & 0.236 \\
& $(0.067)$ & $(0.095)$ & $(0.058)$ & $(0.067)$ & $(0.089)$ & $(0.111)$ \\
& $(-3.256)$ & $(0.060)$ & $(-0.773)$ & $(3.160)$ & $(-1.503)$ & $(2.120)$ \\
CointEq2 & -0.009 & -0.359 & -0.026 & -0.017 & -0.061 & -0.183 \\
& $(0.060)$ & $(0.084)$ & $(0.051)$ & $(0.060)$ & $(0.078)$ & $(0.098)$ \\
& $(-0.154)$ & $(-4.237)$ & $(-0.506)$ & $(-0.290)$ & $(-0.778)$ & $(-1.854)$
\end{tabular}




\begin{tabular}{|c|c|c|c|c|c|c|}
\hline bintEq3 & $\begin{array}{c}0.113 \\
(0.095) \\
(1.188)\end{array}$ & $\begin{array}{c}0.332 \\
(0.134) \\
(2.482)\end{array}$ & $\begin{array}{c}-0.132 \\
(0.081) \\
(-1.616)\end{array}$ & $\begin{array}{c}0.324 \\
(0.095) \\
(3.401)\end{array}$ & $\begin{array}{c}0.425 \\
(0.124) \\
(3.405)\end{array}$ & $\begin{array}{c}0.022 \\
(0.156) \\
(0.145)\end{array}$ \\
\hline $\begin{array}{l}\text { D(RAJSHAHI } \\
(-1))\end{array}$ & $\begin{array}{c}-0.187 \\
(0.098) \\
(-1.892)\end{array}$ & $\begin{array}{c}-0.116 \\
(0.139) \\
(-0.836)\end{array}$ & $\begin{array}{c}0.026 \\
(0.085) \\
(0.310)\end{array}$ & $\begin{array}{l}-0.177 \\
(0.099) \\
(-1.792)\end{array}$ & $\begin{array}{c}-0.060 \\
(0.129) \\
(-0.463)\end{array}$ & $\begin{array}{c}-0.032 \\
(0.162) \\
(-0.202)\end{array}$ \\
\hline $\begin{array}{l}\text { D(RAJSHAHI } \\
(-2))\end{array}$ & $\begin{array}{c}-0.121 \\
(0.091) \\
(-1.336)\end{array}$ & $\begin{array}{c}-0.015 \\
(0.128) \\
(-0.123)\end{array}$ & $\begin{array}{c}0.088 \\
(0.078) \\
(1.128)\end{array}$ & $\begin{array}{l}-0.126 \\
(0.091) \\
(-1.383)\end{array}$ & $\begin{array}{c}0.088 \\
(0.119) \\
(0.739)\end{array}$ & $\begin{array}{c}0.135 \\
(0.149) \\
(0.907)\end{array}$ \\
\hline $\begin{array}{l}\text { D(SYLHET } \\
(-1))\end{array}$ & $\begin{array}{c}0.019 \\
(0.068) \\
(0.282)\end{array}$ & $\begin{array}{c}-0.271 \\
(0.096) \\
(-2.812)\end{array}$ & $\begin{array}{c}0.042 \\
(0.058) \\
(0.717)\end{array}$ & $\begin{array}{c}-0.051 \\
(0.068) \\
(-0.753)\end{array}$ & $\begin{array}{c}0.063 \\
(0.089) \\
(0.707)\end{array}$ & $\begin{array}{c}0.004 \\
(0.112) \\
(0.038)\end{array}$ \\
\hline $\begin{array}{l}\text { D(SYLHET } \\
(-2))\end{array}$ & $\begin{array}{c}0.024 \\
(0.059) \\
(0.406)\end{array}$ & $\begin{array}{c}-0.080 \\
(0.084) \\
(-0.960)\end{array}$ & $\begin{array}{c}0.006 \\
(0.051) \\
(0.125)\end{array}$ & $\begin{array}{l}-0.117 \\
(0.059) \\
(-1.957)\end{array}$ & $\begin{array}{c}0.114 \\
(0.078) \\
(1.458)\end{array}$ & $\begin{array}{c}0.106 \\
(0.098) \\
(1.077)\end{array}$ \\
\hline $\begin{array}{l}\text { D(KHULNA } \\
(-1))\end{array}$ & $\begin{array}{c}0.145 \\
(0.129) \\
(1.129)\end{array}$ & $\begin{array}{c}-0.224 \\
(0.181) \\
(-1.234)\end{array}$ & $\begin{array}{c}0.073 \\
(0.111) \\
(0.661)\end{array}$ & $\begin{array}{l}-0.195 \\
(0.129) \\
(-1.513)\end{array}$ & $\begin{array}{c}-0.123 \\
(0.169) \\
(-0.728)\end{array}$ & $\begin{array}{c}0.295 \\
(0.212) \\
(1.390)\end{array}$ \\
\hline $\begin{array}{l}\text { D(KHULNA } \\
(-2))\end{array}$ & $\begin{array}{c}0.055 \\
(0.114) \\
(0.481)\end{array}$ & $\begin{array}{c}-0.021 \\
(0.161) \\
(-0.134)\end{array}$ & $\begin{array}{c}-0.019 \\
(0.098) \\
(-0.197)\end{array}$ & $\begin{array}{l}-0.091 \\
(0.114) \\
(-0.791)\end{array}$ & $\begin{array}{c}-0.347 \\
(0.150) \\
(-2.310)\end{array}$ & $\begin{array}{c}0.124 \\
(0.188) \\
(0.658)\end{array}$ \\
\hline $\begin{array}{l}\text { D(DHAKA } \\
(-1))\end{array}$ & $\begin{array}{c}-0.033 \\
(0.092) \\
(-0.361)\end{array}$ & $\begin{array}{c}-0.074 \\
(0.129) \\
(-0.577)\end{array}$ & $\begin{array}{c}-0.080 \\
(0.079) \\
(-1.017)\end{array}$ & $\begin{array}{c}0.044 \\
(0.092) \\
(0.480)\end{array}$ & $\begin{array}{c}0.046 \\
(0.121) \\
(0.382)\end{array}$ & $\begin{array}{c}0.104 \\
(0.151) \\
(0.690)\end{array}$ \\
\hline $\begin{array}{l}\text { D(DHAKA } \\
(-2))\end{array}$ & $\begin{array}{c}-0.091 \\
(0.083) \\
(-1.098)\end{array}$ & $\begin{array}{c}-0.019 \\
(0.117) \\
(-0.168)\end{array}$ & $\begin{array}{c}-0.008 \\
(0.071) \\
(-0.119)\end{array}$ & $\begin{array}{c}0.069 \\
(0.083) \\
(0.825)\end{array}$ & $\begin{array}{c}-0.039 \\
(0.109) \\
(-0.358)\end{array}$ & $\begin{array}{c}0.222 \\
(0.137) \\
(1.615)\end{array}$ \\
\hline $\begin{array}{l}\text { D(CHITTA } \\
(-1))\end{array}$ & $\begin{array}{c}0.070 \\
(0.074) \\
(0.941)\end{array}$ & $\begin{array}{c}0.285 \\
(0.105) \\
(2.715)\end{array}$ & $\begin{array}{c}-0.071 \\
(0.064) \\
(-1.105)\end{array}$ & $\begin{array}{c}0.130 \\
(0.074) \\
(1.741)\end{array}$ & $\begin{array}{c}-0.396 \\
(0.098) \\
(-4.042)\end{array}$ & $\begin{array}{c}-0.101 \\
(0.122) \\
(-0.819)\end{array}$ \\
\hline $\begin{array}{l}\text { D(CHITTA } \\
(-2))\end{array}$ & $\begin{array}{c}0.052 \\
(0.069) \\
(0.748)\end{array}$ & $\begin{array}{c}0.076 \\
(0.097) \\
(0.779)\end{array}$ & $\begin{array}{c}0.026 \\
(0.059) \\
(0.447)\end{array}$ & $\begin{array}{c}0.069 \\
(0.069) \\
(0.997)\end{array}$ & $\begin{array}{c}-0.030 \\
(0.091) \\
(-0.329)\end{array}$ & $\begin{array}{c}-0.013 \\
(0.114) \\
(-0.119)\end{array}$ \\
\hline $\begin{array}{l}\text { D(BARISAL } \\
(-1))\end{array}$ & $\begin{array}{c}0.088 \\
(0.054) \\
(1.627)\end{array}$ & $\begin{array}{c}0.151 \\
(0.076) \\
(1.986)\end{array}$ & $\begin{array}{c}0.057 \\
(0.046) \\
(1.241)\end{array}$ & $\begin{array}{c}0.181 \\
(0.054) \\
(3.359)\end{array}$ & $\begin{array}{c}-0.032 \\
(0.070) \\
(-0.456)\end{array}$ & $\begin{array}{c}-0.105 \\
(0.088) \\
(-1.181)\end{array}$ \\
\hline $\begin{array}{l}\text { D(BARISAL } \\
(-2))\end{array}$ & $\begin{array}{c}0.030 \\
(0.056) \\
(0.536)\end{array}$ & $\begin{array}{c}0.239 \\
(0.079) \\
(3.007)\end{array}$ & $\begin{array}{c}0.084 \\
(0.048) \\
(1.728)\end{array}$ & $\begin{array}{c}-0.014 \\
(0.056) \\
(-0.251)\end{array}$ & $\begin{array}{c}0.184 \\
(0.074) \\
(2.485)\end{array}$ & $\begin{array}{c}-0.050 \\
(0.093) \\
(-0.547)\end{array}$ \\
\hline
\end{tabular}




\begin{tabular}{|c|c|c|c|c|c|c|}
\hline R-squared & 0.215 & 0.361 & 0.098 & 0.302 & 0.397 & 0.147 \\
\hline $\begin{array}{l}\text { Adj. R- } \\
\text { squared }\end{array}$ & 0.133 & 0.295 & 0.004 & 0.230 & 0.334 & 0.058 \\
\hline Sum sq. resids & 0.015 & 0.030 & 0.011 & 0.015 & 0.026 & 0.041 \\
\hline S.E. equation & 0.010 & 0.015 & 0.009 & 0.010 & 0.014 & 0.017 \\
\hline F-statistic & 2.627 & 5.429 & 1.046 & 4.159 & 6.311 & 1.661 \\
\hline \multicolumn{6}{|l|}{ likelihood } & 397.599 \\
\hline Akaike AIC & -6.130 & -5.446 & -6.432 & -6.127 & -5.588 & -5.135 \\
\hline Schwarz SC & -5.827 & -5.143 & -6.130 & -5.825 & -5.285 & -4.833 \\
\hline $\begin{array}{l}\text { Mean } \\
\text { dependent }\end{array}$ & 0.0005 & 0.0007 & 0.0008 & 0.0007 & 0.0007 & 0.0003 \\
\hline $\begin{array}{l}\text { S.D. } \\
\text { dependent }\end{array}$ & 0.011 & 0.018 & 0.009 & 0.012 & 0.017 & 0.018 \\
\hline \multicolumn{2}{|c|}{$\begin{array}{l}\text { Determinant Residual } \\
\text { Covariance }\end{array}$} & 4.27E-24 & & & & \\
\hline \multicolumn{2}{|l|}{ Log Likelihood } & 2740.307 & & & & \\
\hline \multicolumn{2}{|c|}{ Akaike Information } & -35.292 & \multicolumn{3}{|c|}{ Criterion } & \\
\hline \multicolumn{2}{|c|}{ Schwarz Criterion } & -33.054 & & & & \\
\hline
\end{tabular}

Note: Included observations 149, 3 after adjusting endpoints.

Standard errors and $t$-statistics in parentheses and the numbers in parentheses in the first column refers to the lag order. 


\section{References}

Alexander, C. and Wyeth, J. (1994). Co-Integration and Market Integration: Application to the Indonesian Rice Market. Journal of Development Studies, 30(2), 303-328.

Barrett, C.B. (1996). Market Analysis Methods: Are our Enriched Toolkits Well Suited to Enlivened Markets? American Journal of Agricultural Economics, 78(3), 825-829.

Baulch, B. (1997). Transfer Costs, Spatial Arbitrage and Testing Food Market Integration. American Journal of Agricultural Economics, $79(2), 477-487$.

Baulch, R., Das, J., Jain, W. M. H., Farid, N. and, Zohir S. (1998). The Spatial Integration and Pricing Efficiency of the Private Sector Grain Trade in Bangladesh. Phase I and II report. Bangladesh Institute of Development Studies. Bangladesh Agricultural University and University of Sussex.

Boyd, M., and Brorsen, B.W. (1986). Dynamic Price Relationships for US and EC Corn Glutten Feed and Related Markets. European Review of Agricultural Economics, 13, 199-215.

Chang, H.S., and Griffith G. (1998). Examining Long-run Relationships between Australia Beef Prices. Australian Journal of Agricultural and Resource Economics, 42(4), 369-387.

Delgado, C.L. (1986). A Variance-Components Approach to Food Grain Market Integration in Northern Nigeria. American Journal of Agricultural Economics, 68(4), 970-979.

Dercon, S. (1995). On Market Integration and Liberalization: Method and Application to Ethiopia. Journal of Development Studies, 32(1), 112143.

Dickey, D.A., and Fuller, W.A. (1979). Distribution of the Estimators for Autoregressive Time Series with a Unit Root. Journal of the American Statistical Association, 74(366), 427-431. 
Dickey, D.A., and Fuller, W.A. (1981). Likelihood Ratio Statistics for Autoregressive Time Series with a Unit Root. Econometrica, 49(4), 1057-1072.

Engle, R.A., and Granger, C.W.J. (1987). Cointegration and Error Correction: Representation, Estimation and Testing. Econometrica, 55(2), 251-76.

Fackler, P. (1996). Spatial Price Analysis: A Methodological Review. Mimeo, North Carolina State University.

Food and Agriculture Organization (FAO) (1987). Agricultural Price Policies: Issues and Proposals. FAO Economic and Social Development Series No. 40. Rome.

Farruk, M.O. (1970). The Structure and Performance of the Rice Marketing System in East Pakistan. Occasional Paper No. 31. Department of Agricultural Economics. Cornell University Press, Ithaca, NY.

Getnet, K., Verbeke, W., and Viaene, J. (2005). Modeling Spatial Price Transmission in the Grain Markets of Ethiopia with an application of ARDL approach to White Teff. Agricultural Economics. 33(3), 491-502.

Goletti, F., and Babu, S. (1994). Market Liberalization and Integration of Maize Markets in Malawi. Agricultural Economics, 11 (2/3), 311-24.

Goletti, F., Ahmed, R., and Farid, N. (1995). Structural Determinants of Market Integration: The Case of Rice Markets in Bangladesh. The Developing Economics, 33(2), 185-202.

Gupta, S., and Mueller, R. (1982). Analyzing the Price Efficiency in Spatial Markets: Concept and Application. European Review of Agricultural Economics, 9, 24-40.

Harriss, B. (1979). There is Method in my Madness: Or is it Vice Versa? Measuring Agricultural Market Performance. Food Research Institute Studies, 17, 197-218.

Heytens, P. (1986). Testing Market Integration. Food Research Institute Studies, 20 (1), 25-41. 
Hopcraft, P. (1987). Grain Marketing Policies and Institutions in Africa. Finance and Development, 24 (1), 37.

Johansen, S.K., and Juselius, K. (1990). Maximum Likelihood Estimation and Inference on Cointegration with Application to the Demand for Money. Oxford Bulletin of Economics and Statistics, 52, 169-210.

Johansen, S.K. (1988). Statistical Analysis of Cointegration Vectors. Journal of Economic Dynamics and Control, 12, 231-254.

Johansen, S.K. (1991). Estimation and Hypothesis Testing of Cointegration Vectors in the Presence of Linear Trend. Econometrica, 59, 151-58.

Jones, W.O. (1968). The Structure of Food Marketing in Nigeria as Revealed by Price Analysis. Food Research Institute Studies, 8 (2), 95-124.

Jones, W.O. (1972). Marketing Staple Food Crops in Tropical Africa. Cornell University Press: Ithaca, NY.

Lele, U. (1972). Food Marketing in India: Private Performance and Public Policy. Cornell University Press: Ithaca, NY.

Myers, R.J. (1994). Time Series Econometrics and Commodity Price Analysis: A Review. Review of Marketing and Agricultural Economics. 62, 167-181.

Onafowora, O.E., and Owoye, O. (1998). Can Trade Liberalization Stimulate Economic Growth in Africa? World Development, 26(3), 497-506.

Palaskas, T., and Harriss, W.B. (1993). Testing Market Integration: New Approaches, with Case Material for the West Bengal Economy. Journal of Development Studies, 13 (1), 1-57.

Perron, P. (1988). Trends and Random Walks in Macroeconomic Time Series. Journal of Economic Dynamics and Control, 12, 297-332.

Ravallion, M. (1986). Testing Market Integration. American Journal of Agricultural Economics, 68, 102-109. 
Sexton, R., Kling, C., and Carman, H. (1991). Market Integration, Efficiency of Arbitrage and Imperfect Competition: Methodology and Application to U.S. Celery. American Journal of Agricultural Economics, 7, 568-580.

Silumbu, A. (1992). Changing Marketing Environment, Emerging Pricing Issues and Policy in Malawi, in J.B. Wyckoff and Mandivamba Rukuni (eds.) Food Security Research in Southern Africa: Policy Implications. University of Zimbabwe/Michigan State University. Food Security Research in South Africa Project. Department of Agricultural Economics and Extension. Harare.

Silvapulle, P., and Jayasuriya, S. (1994). Testing for Philippines Rice Market Integration: A Multiple Co-Integration Approach. Journal of Agricultural Economics, 45(3), 369-380. 